\title{
A REVISION OF CERTAIN SPECIES OF PLANTS OF THE GENUS ANTENNARIA.
}

\author{
By Elias Nelson. \\ Scientific Aid, U. S. Department of Agriculture.
}

Recent study of the genus Antennaria in North America has been confined almost entirely to the group represented by $A$. alpina, $A$. dioica, and A. plantaginifolia of Gray's Synoptical Flora. These, as treated by Dr. Gray, have proved to be aggregates. The names $A$. alpina and $A$. dioica were originally applied to Old World plants, and it appears that no American specimens are referable to those species. Prior to 1897 only five species of the North American continent had been described in this group, viz, A. plantaginifolia (Linnæus) Richardson, A. monocephala De Candolle, A. solitaria Rydberg (A. plantaginifolia monocephala Torrey and Gray), A. parvifolia Nuttall, and A. labradorica Nuttall. During the last four years, however, about 50 additional species have been published. The Antennarias of many parts of North America are as yet little known, and much research in connection with the genus is still necessary. Mr. Fernald has succeeded in arriving at a very satisfactory arrangement of the New England Antennarias. Those of other regions are in need of similar study.

In this paper an attempt is made at a natural arrangement of the western and northern species of this group. A tolerably satisfactory synopsis can hardly be expected until more material from this rast region is at hand. Many of the species are very imperfectly known; a considerable number from their type localities only. Especially is this true of the far northern species. Because of the great variability of the species and their very frequent and perplexing intermediate forms, a reasonably complete series of specimens representing each must be obtained before its claim to specific rank can be considered fully established. When more material is secured, it may be found that too many species have been recognized in this paper.

In the study of this genus it is of the greatest importance that the identity of each published species be definitely determined. I have been very fortunate in having had the opportunity of examining types or typical material of all the species included in this paper except A. parvifolia, A. monocephala, and $A$. aizoides. The last named is the only species of which I have seen no specimens. Although I have 
not seen the types of any of Dr. Rydberg's species, I have examined duplicates of all of them. This preliminary revision is based principally on the material in the United States National Herbarium and in my private collection of Antennarias. I am under great obligation to Dr. E. L. Greene for the privilege of examining types and typical specimens of the species which he has described; and through the kindness of Mr. J. M. Macoun it has been possible for me to study the types and other material preserved in the herbarium of the Geological Survey of Canada. I owe much to Mr. Frederick V. Coville and Dr. J. N. Rose, who have in many ways greatly aided me in the study of this genus and in the preparation of this paper.

The results of my investigation are incorporated in the following presentation of the species:

SYNOPSIS OF THE SPECIES OF ANTENNARIA, ALLIED TO A. ALPINA AND A. DIOICA, OCCURRING IN NORTHERN AND WESTERN NORTH AMERICA.

a. Leares comparatively small. (aa on page 713.)

b. Tips of involucral bracts green to pale brown. Segregates of A. ALPINA of the Srnoptical Flora. (A. arida may be looked for here.) (bb on page 704.)

c. Heads solitary or 1-3. (cc on page 699.)

1. Antennaria monocephala DC. Prodr. 6:269. $16+3$.

Slender, 9-11 cm. high, the stolons about $1 \mathrm{~cm}$. long; leaves narrowly oblanceolate, acute, and cuspidate-mucronate, 10-15 mm. long, green and glabrate above; stem floccose-woolly, with leaves less than $1 \mathrm{~cm}$. long; involucres $5.5 \mathrm{~mm}$. high, the bracts (of pistillate heads) comparatively broad ( $1 \mathrm{~mm}$. or less), obtuse, brown but lighter in color toward the very tips.

Type locality. - "In insula Unalaschka". Type either in the De Candollean or the Berlin Herbarıum.

Known to me only from the island of Unalaska and from near Nome City, Alaska (Flett, no. 1655, Anvil Mountain, 1900).

The above description is drawn from the specimen in the herbarium of the Geological Survey of Canada, collected by J. M. Macoun on "mountain summits," Unalaska, Bering Sea, August 22, 1891. The Alaskan specimens collected by J. B. Flett, examined by me, are all male plants. The tips of the bracts are oblong and obtuse and greenish brown, while the pappus bristles are like those of $A$. exilis.

2. Antennaria exilis Greene, Pittonia $3: 288.1898$.

Low, slender, 2-8 cm. high, the stolons short; leaves spatulate, acute, 7-12 mm. long, lightly woolly on both surfaces, heads solitary; involucres about $4.5 \mathrm{~mm}$. high, the pistillate bracts acute or acuminate, the staminate obtuse or acutish.

Type locality._- "St. Paul Island, Bering Sea." Collected by J. M. Macoun and by Kincaid; type in the herbarium of E. L. Greene. 
Known also from Kyska Island (Baker), one of the western Aleutian Islands, and from Unalaska (Flett, no. 1789, 1900).

Closely related to $A$. monocephala, but a smaller plant with narrower pistillate bracts.

3. Antennaria angustata Greene, Pittonia 3:284. 1898.

Tufted, $t-7 \mathrm{~cm}$. high, with short suberect offsets; stems leafy; leaves linear or very narrowly spatulate, $12-20 \mathrm{~mm}$. long, becoming glabrate above; cauline leaves linear, spreading, the tips of at least the upper ones scarious and greenish brown or white; heads large, $1-3$, usually solitary; involucres (pistillate) $6-7 \mathrm{~mm}$. high, the bracts green or brown, nearly all acuminate. Male plant unknown.

Type locality._- "Coasts of Hudsons Strait." Collected by Bell; type in the herbarium of the Geological Survey of Canada (sheet no. 11248).

The type sheet contains 4 plants, representing two collections; one from Cape Prince of Wales, in which the plants (2) are about $7 \mathrm{~cm}$. high and with very narrow leaves; the other from Cape Chudleigh, the plants being $+\mathrm{cm}$. high and with leaves shorter and broader in proportion.

4. Antennaria aizoides Greene, Pittonia $3: 233.1898$.

-Very loosely crespitose, the branches rigid, stout, ascending, scarcely stolon-like, the leaves forming a rosette at summit, these thick and firm in texture, spatulate from a broad, rounded, and obtuse terminal portion, permanently silvery-white on both sides with a dense tomentum, not in the least viscid; peduncles an inch high, linearbracted, bearing at summit about three small sessile heads; scarious tips of the involucral bracts dull brownish, those of the outer ovate, of the inner obovate; pappus bristles (only the male known) apparently oblanceolate from toward the base, serrulate."

Type locality.- "Dry, barren ground among the Cypress Hills, Northwest Territory." Collected by John Macoun; type in the herbarium of the Geological Survey of Canada (sheet no. 11245).

Since I have seen no specimens of this species, I quote Dr. Greene's description.

cc. Heads few to many. ${ }^{1}$

d. Far-northern species.

${ }^{1}$ The following species, known to occur in Greenland, have apparently not been found on the American continent:

1. Antennaria alpina (L.) Gaertn. Fruct. 2: 410. 1791. Gnaphalium alpinum L. Sp. Pl. 856.1753. Leaves oblanceolate, $2-3.5 \mathrm{~mm}$. broad, green and glabrate above; heads several, small and narrow, the involucral bracts (pistillate) acuminate; pappus of the staminate heads not at all dilated at apex.

Type locality.--"In Alpibus Lapponiæ."

2. Antennaria glabrata (Vahl) Greene, Pittonia $3: 285$. 1898. A. alpina glabrata Vahl, in Fl. Danica $47: \mathrm{pl}$. 2786. fig. g. 1868. Entirely glabrous; closely related to the preceding. For full description, see Greene, Pittonia $3: 285.1898$. Type in the Botanical Museum at Copenhagen, collected by Vahl on the island of Disco ("paa Oen Disco"), off the west coast of Greenland. 


\section{Antennaria pallida nom. nov.}

A. borealis Greene, Pittonia 4: 85. 1899, not Gandoger, 1887.

From 6 to $15 \mathrm{~cm}$. high; stolons short; leaves spatulate-oblanceolate, acute, 10-15 mm. long, lightly and permanently soft-woolly on both surfaces; heads comparatively large, $2-7$; involucres $6 \mathrm{~mm}$. high; tips of the bracts (pistillate) broad and obtuse, dirty white or brownish in color. Male plant unknown.

Type locality.- "Disenchantment Bay, Alaska." Collected by Funston, no. 101; type in the herbarium of E. L. Greene.

Alaska (Funston, no. 101; Flett, no. 1652, near Nome City, 1900.)

This resembles $A$. monocephala in the general outline of its leaves and in its broad-bracted involucres. Its heads are considerably larger than those of $A$. media.

\section{dd. Species of the western United States and of the Rocky Mountains of southern British America.}

6. Antennaria media Greene, Pittonia 3: 286. 1898.

Rarely more than $6 \mathrm{~cm}$. high; stolons $1-3 \mathrm{~cm}$. long; leaves spatulateoblanceolate, often narrowly so, abruptly acute or acute, $15 \mathrm{~mm}$. or less long, white or grayish-tomentose on both surfaces; involucres (pistillate) about $4 \mathrm{~mm}$. high; tips of the pistillate bracts oblong to oblong-linear, obtuse, rarely acutish, green, greenish brown, rarely light brown and whitish at the very tips; tips of the staminate bracts oval, obtuse, of same color as the pistillate ones.

Type locality.- " Mountains above Coldstream, Placer County, California." Collected by Sonne; type in the herbarium of E. L. Greene.

From the mountains of California to British Columbia and in the Rocky Mountains from Colorado to Alberta.

While typical $A$. media is found in the mountains of the Pacific coast States, there occur in the Rocky Mountains plants which agree so closely with the far-western ones that they must be referred to the same species. As in A umbrinella, the leaves of the last season are often green and glabrous. The male plants, though much less common than the female, are not rare, and, as noted by Dr. Greene, their pappus bristles are very distinctly dilated at apex, in this respect very different from those of $A$. alpina.

Antennaria media ciliata subsp. nov.

Depauperate, less than $3 \mathrm{~cm}$. high, beset with minute, short, glandular-tipped hairs about the glomerule, on the foliar bracts and lower half of the leaves.

Type locality.-White Mountains, Mono County, California. Collected by Shockley, no. 444; type in the United States National Herbarium.

In the White Mountains (Shockley, 1886) and Sierra Nevada (Covilie and Funston, no. 2160, 1891, near Farwell Gap) of California.

7. Antennaria macounii Greene, Pittonia 3: 276. 1898.

Stems $4-7 \mathrm{~cm}$. high; stolons slender, leafy terminally, $2-4 \mathrm{~cm}$. long; 
leaves spatulate, the terminal portion broad and only abruptly acute, 11-14 mm. long, $4 \mathrm{~mm}$. or less broad, striately hoary-tomentose; involucres about $5.5 \mathrm{~mm}$. high, the tips of the bracts (pistillate) narrow, obtuse or acute, greenish brown, rarely whitish. Male plant unknown.

Type locality.- " Revelstoke, B. C." Collected by John Macoun; type in the herbarium of the Geological Survey of Canada (sheet no. 11241).

Only the type specimen seen.

This is very closely related to $A$. umbrinella, having the same indument and somewhat similar heads but more spatulate leaves. It is also closely related to $A$. media, the only very striking difference being that its leaves are more dilated terminally.

\section{Antennaria tomentella sp. nov.}

Cespitose, about $1 \mathrm{dm}$. high, with slender stems and procumbent, somewhat flexible stolons; leaves oblanceolate, acute, prominently mucronate, $16-20 \mathrm{~mm}$. long, tomentose or canescent beneath, sparsely so above, the indument more or less persistent; cauline leaves linear, acute to acuminate; heads 4-6, glomerate; involucres 5-6 mm. high; bracts (pistillate) in 2-3 series, nearly all obtuse, the tips greenish brown, oval in the outer to oblong or linear-oblong in the inner. Male piant unknown.

Type locality.-Near Stevens Pass, Cascade Mountains, Washington. Collected by Sandberg and Leiberg, no. 751; type in the United States National Herbarium.

The leaves of this plant are noticeably larger than in related species, and the very light indument of the upper surface is quite characteristic.

9. Antennaria umbrinella Rydb. Bull. Torr. Club 24:302. 1897.

A. mucronata E. Nelson, Bot. Gaz. 27:209. 1899. ${ }^{1}$

Ten to $15 \mathrm{~cm}$. high; stolons $4 \mathrm{~cm}$. long or less; leaves narrowly spatulate-oblanceolate, acute or abruptly acute and mucronate, 15-25 $\mathrm{mm}$. long, canescent on both surfaces, rarely tomentose; involucres 5-6 mm. high; tips of the bracts (pistillate) oblong or oblong-lanceolate, obtuse, rarely acutish, greenish brown, the very tips often whitish. Typical male plants unknown.

Type locality.- "Long Baldy, in the Little Belt Mountains," Montana. Collected by Flodman, no. 859 (in part); type in the herbarium of the New York Botanical Garden.

Wyoming and Montana to Oregon (Coville and Leiberg, no. 431.) This species is nearer to the European $A$. alpina than any other West American Antennaria. It is very difficult to separate from $A$. media. It is, however, a much larger plant, with larger heads and leaves which are canescent rather than tomentose. The two species apparently intergrade, and it is probable that $A$. media can not be

${ }^{1}$ Type locality._- "La Plata mines, in the Medicine Bow mountains," Wyoming. Collected by Elias Nelson, no. 5211; type in the Rocky Mountain Herbarium, University of Wyoming, Laramie. 
maintained except as a variety. A. umbrinella is found only at high elevations in the mountains.

In describing $A$. umbrinella Dr. Rydberg confused two species. I would hesitate to make this assertion had I not examined two cotypes, and Dr. Rydberg has sent me a male and a female head taken from the type sheet. The male and female plants of his type are of different species. One of these he later named A. flavescens, and the staminate plants of this and his $A$. umbrinella are identical. The name $A$. umbrinella must be applied to the species represented by the female plants of his type, since the species represented by the male plants was described by me as $A$. reflexa and by Dr. Rydberg, as already noted, as A. flavescens. In this connection it may be well to call attention to the more salient characters of the male and female plants of the type of the original A. umbrinella. The leaves of the staminate (A. reflexa) are spatulate, obtuse or abruptly acute, and with an appressed tomentum. The leaves of the pistillate are narrower and mucronate; the indument lighter and looser, canescent rather than tomentose. $A$. umbrinella is quite different in general appearance from $A$. reflexa and is much more readily separated from it than from $A$. media.

The bracts of the type are much broader than in some other specimens, such as Flodman's no. 862, which duplicates the type very nicely as to leaves and habit.

\section{Antennaria pulvinata Greene, Pittonia 3: 287. 1898.}

Pulvinately cespitose, with very short, rosulate-leafy closely compacted offsets; stems $4-10 \mathrm{~cm}$. high; leaves spatulate-obovate to spatulate, obtuse or only abruptly acute, about $1 \mathrm{~cm}$. long, white-tomentose on both surfaces; involucres $6-7 \mathrm{~mm}$. high, the bracts (pistillate) either broad and imbricated or narrow and fewer and nearly equal, their tips obtuse or acute, black-green to brown in color. Male plant unknown.

Type locality._- "Alberta." Collected by John Macoun, nos. 18491, 18493, 18495, 18498; type sheets in the herbarium of E. L. Greene.

Alberta, British Columbia, and Montana (R. S. Williams, no. 729).

In habit and leaves this is very different from the related $A$. umbrinella, A. macounii, and A. media. In its involucres this species presents a variation which is almost dimorphic. In several other species a variation as to the breadth and length of the involucral bracts may be noticed, but in none is it as prominent as in this. The form with the broad-bracted and imbricated involucres was mistaken by Dr. Greene for the male plant, while the one with narrow bracts is the "female plant" of his description.

Antennaria pulvinata albescens subsp. nov.

About $4 \mathrm{~cm}$. high; leaves $5-8 \mathrm{~mm}$. long; involucres about $5 \mathrm{~mm}$. high; bracts (pistillate) imbricated and in about 3 series, rarely nearly equal, their tips oval to oblong, obtuse, sordid white, pinkish white, or pale brown.

Type locality.-Mount Fops, Salmon River Mountains, Texas district, Idaho. Collected by Henderson, no. 3870; type in the United States National Herbarium.

Idaho (Henderson, 1895) and Montana (Rydberg and Bessey, no. $5162)$. 
This has the pulvinate habit and imbricated involucres of the species, but is smaller in every way, and the tips of the bracts are much lighter in color. It may prove to be a distinct species.

11. Antennaria austromontana sp. nov.

Cespitose, the stems stout, leafy, about $5 \mathrm{~cm}$. high; leaves spatulate, obtuse, or abruptly acute, 8-15 mm. long, 4-5 mm. broad, loosely woolly on both surfaces; lower cauline leaves oblong-linear, nearly as broad as and longer than those of the short stolons; heads rather large, $3-5$, the lower one or two often on pedicels $5-10 \mathrm{~mm}$. long; involucres about $6 \mathrm{~mm}$. high; bracts (pistillate) more or less unequal, in about 3 series, their tips rather broad, ovate in the outer to oblong or lanceolate in the inner, obtuse, blackish green or brown, the very tips often pale brown. Male plant unknown.

Type locality.-Marysvale, Utah. Collected by Jones, no. 5522; type in the United States National Herbarium.

Utah (Jones, nos. 5522, 5770i) and Colorado (Baker, Earle and Tracy, no. 626).

A low, rather stout species, with ample cauline leaves, much less matted than $A$. pulvinata, but resembling it in its heads and in the general outline of its leaves. The indument is loose and dull white or grayish in color, not appressed and shining, as in that species. It is distinguished from $A$. media by its larger heads and obtuse leaves, while as compared with $A$. umbrinella it has broader leaves and is a lower and much stouter plant.

12. Antennaria fusca E. Nelson, Bot. Gaz. $30: 120.1900$.

About $1 \mathrm{dm}$. high; leaves spatulate, obtuse and more or less truncate at apex, indistinctly mucronate, about $2 \mathrm{~cm}$. long, $5-7 \mathrm{~mm}$. broad, canescently tomentulose or striate woolly on both surfaces; involucres 6-7 mm. high, the tips of the bracts (pistillate) oblong or oblonglinear, obtuse, greenish brown to buff color. Male plant unknown.

Type locality. - "On dry bottoms and in open woods on Lewis river, Yellowstone park," Wyoming. Collected by Aven and Elias Nelson, no. 6356; type in the Rocky Mountain Herbarium, University of Wyoming, Laramie.

Known to me only from type locality and from the Medicine Bow Mountains of southern Wyoming (Aven Nelson, no. 7901, 1900).

This is nearest to $A$. umbrinella, but has larger heads, and leaves more like those of $A$. aprica. The heads are on longer pedicels than is usually the case in the species of this group.

13. Antennaria reflexa E. Nelson, Bot. Gaz. 27 : 208. 1899.

A. flavescens Rydb. Mem. N. Y. Bot. Garden 1: 411. 1900. ${ }^{1}$

Slightly suffrutescent, $5-15 \mathrm{~cm}$. high; leaves spatulate or spatulateobovate, obtuse, 6-15 mm. long, usually $1 \mathrm{~cm}$., dull, grayish-white tomentose on both surfaces; involucres $4-5 \mathrm{~mm}$. high, the bracts few,

${ }^{1}$ Type locality, "Bridger Mountains," Montana. Collected by Rydberg and Bessey, no. 5145 ; type in the herbarium of the New York Botanical Garden. 
in less than 3 series, the tips of the pistillate usually from oval in the outer to oblcng-linear in the inner, all obtuse, less frequently ovate or lanceolate in the outer to linear in the inner and acute or acuminate, in color from greenish brown to yellowish white, rarely rose color, tips of the staminate oval, obovate or oblong, obtuse or truncate, usually of firm texture, like the pistillate ones as to color.

Type locality._- "Centennial Valiey," southern Wyoming. Collected by Aven Nelson, no. 1265; type in the Rocky Mountain Herbarium, University of Wyoming, Laramie.

Wyoming and Montana.

A dry ground species, occurring on high hills and occasionally on open plains at subalpine elevations. It is characterized by its short, very plain, obtusish leaves, which are invested with an appressed and often yellowish tomentum. The heads are very small and the tips of the staminate bracts are rather firm in texture and inclined to be folded back. The type of the species is a form with acute, green, pistillate bracts and greenish brown staminate ones. Dr. Rydberg based his A. Alavescens (no. 5145 , the type of this, is composed of staminate plants.) on specimens which as to habit and leaves are essentially those of the type of $A$. reflexa. The bracts, however, are lighter in color.

\section{Antennaria confinis Greene, Pittonia 4:40. 1899.}

More or less suffrutescent, the stems slender, about $1 \mathrm{dm}$. high, rarely $15 \mathrm{~cm}$. ; leaves mostly oblong-spatulate, obtusish to acute, about $1 \mathrm{~cm}$. long, rarely longer, tomentose on both surfaces and dull in color; involucres 4-5 mm. high, the bracts few, the tips of the pistillate ones oval to oblong, obtuse, brownish yellow to dull white, tips of the staminate oval or obovate, brownish to nearly white.

Type locality. - "Santa Catalina Mountains, Arizona." Collected by Lemmon; type in the herbarium of E. L. Greene.

Arizona, California (Lemmon, Sierra Nevada Mountains, 1875; Coville and Funston, no. 1658), Nevada (Watson, nos. 650, 651), Oregon (Leiberg, no. 331; Cusick, no. 1924), and Idaho (Henderson, no. 3514).

Nearest to $A$. reflexa and replacing it west of the Rocky Mountains. It approaches very closely to that species, yet the typical form is quite different in being more distinctly suffrutescent and slightly viscid throughout and in having "oblong-spatulate" rather than spatulate leaves and lighter-colored involucral bracts. It is very similar to $A$. arida, being distinguished from the latter by its suffrutescent habit, viscidulous leaves and stems and pale brown bracts.

bb. Tips of involucral bracts not brown or green. Segregates of A. DIOICA of the sYNoptiCAL FLoRA. (Albinos of A. reflexa and A. confinis may be looked for here; also $A$. reflexa with rose-colored bracts.)

\section{Leaves coriaceous.}

15. Antennaria suffrutescens Greene, Pittonia 3:277. 1898.

Leaves small and glabrous above, spatulate; heads solitary.

Type locality._- "Near Waldo, Oregon." Collected by Howell; type in the United States National Herbarium. 
Of all the species of Antennaria that have been recently described this is certainly the most remarkable. It has leaves totally different from at least all North American species. The margins of the lower half are revolute and the very apex is recurved so as to make the leaf appear retuse.

\section{ee. Leaves not coriaceous.}

f. Heads comparatively small, the involucres 5-6 (4-7) mm. high. (ff. on page 711.)

g. Tips of involucral bracts rose color, or rarely whitish. (A. arida with rose-colored bracts may be looked for here.) ( $g g$. on page 707.)

\section{Antennaria concinna sp. nov.}

Cespitose, with leafy offsets or procumbent stolons, the latter at most $5 \mathrm{~cm}$. long; stems slender, leafy, 10-15 cm. high; leaves spatulate with no distinction of blade or petiole, scarcely abruptly acute, about $1 \mathrm{~cm}$. long and $2-4 \mathrm{~mm}$. broad, white-tomentose on both surfaces; the cauline linear-oblong to linear, acute, shorter than the internodes; heads 6-8 and glomerate, or often as many as 15 , and the cluster then rather open; involucres $6-7 \mathrm{~mm}$. high; bracts (pistillate) in about 3 series, all obtuse and about $1 \mathrm{~mm}$. wide, the herbaceous portion of a livid green, the outer bracts with a brown middle portion and their tips light brown, the tips of the others rose color or yellowish white. Male plant unknown.

Type locality.-Olympic Mountains, Clallam County, Washington. Collected by Elmer, no. 2417 (in part); type in the United States National Herbarium.

Washington and Oregon (Cusick, no. 1925, in part) to Utah (Jones, nos. 5375u, 5422e, 5441x.)

This somewhat resembles $A$. pulvinata as to foliage, but its affinities are with $A$. rosea. It is characterized by its short, obtusish, whitetomentose leaves. In $A$. rosea and all its forms the leaves are distinctly acute and the tomentum usually dull and grayish in color. The Utah specimens have larger radical leaves than the type and longer cauline ones.

\section{Antennaria speciosa sp. nov.}

Cespitose, 10-17 cm. high, the stolons short and leafy; leaves narrowly oblanceolate, acutish, 1-2 cm. long, about $4 \mathrm{~mm}$. wide, lightly hoary-tomentose or canescent and permanently so on both surfaces; heads $9-15$ in a rounded cluster, nearly all pedicellate; involucres about $7 \mathrm{~mm}$. high; bracts (pistillate) numerous, imbricated, in about four series, the inner less than half as broad and acute to acuminate, the nonherbaceous portion rose color or nearly white. Male plant unknown.

Type locality.-Bear Valley, in the San Bernardino Mountains, Caiifornia. Collected by Parish, no. 3354; type in the United States National Herbarium.

San Bernardino and San Jacinto (H. M. Hall, no. 718, 1897) Mountains, California.

Proc. N. M. vol. xxiii- 45 
A very pretty species, with much larger heads than $A$. rosea and quite different involucres.

18. Antennaria rosea (Eaton) Greene, Pittonia $3: 281.1898$.

A. parvifolia Nutt. Trans. Am. Phil. Soc. $7: 406.1841$, in part (as to female plant).

A. dioica rosea Eaton, Bot. King Surv. 186. 1871, name only.

A. parvifolia rosea Greene, Pittonia $3: 175$. 1897, name only.

Slender, 2-4 dm. high; sterile basal branches ascending to erect, rarely prostrate; the canescent tomentum of the leaves and the striate wool of the stems slightly viscid; leaves very narrowly oblanceolate or elongated spatulate, acute, $15-20 \mathrm{~mm}$. long, less than $5 \mathrm{~mm}$. wide; heads in close and rounded or often rather open clusters; involucres 5-6 mm. high; bracts (pistillate) in about three series, nearly equal or somewhat imbricated, the tips oval to linear, usually all obtuse, rose color to dull white. Male plant unknown.

From Colorado to Alberta and westward to the Pacific coast.

This is the most widely distributed as well as the most polymorphic of our western species. It runs into numerous and perplexing forms. It usually grows on dry ground, especially on partially wooded slopes, but is often found on the drier bottoms. This species and its variety angustifolia are slightly viscid and oily, as it were. This is especially true of the dull and grayish indument of the radical leaves. Neither in this species nor in its immediate relatives do we find any minute glandular hairs such as often occur in A. parvifolia.

Antennaria rosea angustifolia (Rydb.) comb. nov.

A. angustifolia Rydb. Bull. Torr. Club 26 : 546.1899.

A. sordida Greene, Pittonia 4 : 81. 1899, ${ }^{1}$ not Sch. Bip. 1854.

Lower and more subligneous than the species and more viscid; leaves smaller, often very narrow; inflorescence more congested; heads as in the species and with the same variation as to the color of the bract tips. Male plant exceedingly rare.

Typelocality._- "Yosemite Valley," California. Collected by Torrey; type in the Torrey Herbarium.

As compared with the species, this variety grows in dryer and more exposed situations and at higher altitudes. It grades so imperceptibly into $A$. rosea that its recognition as a species would not be justifiable. In this variety, as often in the species, the leaves when stripped of the indument usually present a granular and livid green surface. The only male plants of the $A$. rosea group of which I have any knowledge are those of Rydberg and Bessey's, no. 5159. These plants appear to belong here rather than with the species. The tips of the bracts are obovate or oval, obtuse, and of a dull white color.

The names $A$. angustifolia and $A$. sordida Greene were applied to plants not materially different. As to leaves and habit they agree very well. The first was based on an albino form of the Sierra Nevada of California and the latter on a low tufted form of higher elevations of the southern Rocky Mountains.

${ }^{1}$ Type locality, "North Park, near Teller," Colorado. Collected by Sheldon, no. 128; type in the herbarium of E. L. Greene. 
Antennaria rosea divaricata subsp. nov.

Stems stout, leafy, 15-20 cm. high; leaves rather large, with a more or less elongated petiolar base and narrowly oblanceolate blade, $2-3$ cm. long, $5-7 \mathrm{~mm}$. broad, the cauline linear or oblong linear spreading, about $25 \mathrm{~mm}$. long. Male plant unknown.

Typelocality.-Divide on the road from Custer to Challis, Idaho. Collected by Henderson, no. 3636; type in the United States National Herbarium.

Washington (Elmer, no. 2419, 1900) and Idaho to Colorado (Baker, Earle and Tracy, no. 655).

Antennaria rosea imbricata E. Nelson, comb. nov.

A. imbricata E. Nelson, Bot. Gaz. 27:211. 1899.

Leaves with obovate or oblanceolate blade, obtusish, $20-25 \mathrm{~mm}$. long, about $5 \mathrm{~mm}$. wide, thin in texture, the indument appressed, whitish; involucral bracts (pistillate) broader than in the species, in about four series, imbricated, rose color to nearly white. Male plant unknown.

Type locality. - "North fork of Crow creek in the Laramie hills," Wyoming. Collected by Elias Nelson, no. 2036; type in the Rocky Mountain Herbarium, University of Wyoming, Laramie.

Wyoming and Montana to California (Hall and Chandler, no. 647, in part) and Oregon (Leiberg, no. 516).

A very good variety, easily distinguished from the species, but connected with it by intermediate forms. It is a meadow plant, somewhat resembling the large-leaved form of $A$. parvifotia of higher altitudes.

gg. Tips of involucral bracts white.

h. Stems 6-30 $\mathrm{cm}$. high, several to many in congested or operi corymbose cymes. ( $h$ h, on page 710 .)

19. Antennaria nardina Greene, Pittonia 4: 82. 1899 (December).

A. corymbosa E. Nelson, Bot. Gaz. 27: 212. 1899 (March), ${ }^{1}$ not A. alpina corymbosa Hartman, 1846(?).

Stem slender, 12-25 cm. high; stolons flexible; leaves from almost linear to narrowly oblanceolate, rarely oblanceolate, acute, cuspidately mucronate, 25-35 mm. long, canescent or lightly tomentose, rarely green and glabrate; heads more or less pedicelled and corymbosely disposed; involucres 4-5 mm. high; bracts with a brownish spot at the middle, the tips dull white or milky white, the pistillate ones ovate to oblong, obtuse, the staminate rotund to oblong, obtuse or truncate. Type locality._-"Mt. Massive, near Leadville, Colorado." Collected by Holm; type (male plants only) in the herbarium of E. L. Greene.

Mountains of Colorado, Wyoming, and Montana.

One of the best of recently described species, being unusually well

${ }^{1}$ Type locality._- "Battle lake, in the Sierra Madre mountains," southern Wyoming. Collected by Aven Nelson, no. 4160; type in the Rocky Mountain Herbarium, University of Wyoming, Laramie. 
marked and less variable than other Rocky Mountain species. It usually grows in wet alpine meadows.

20. Antennaria foliacea Greene, Pittonia 3: 279. 1898.

About $3 \mathrm{dm}$. high; leaves broadly spatulate to cuneate-obovate, thin in texture, $15-20 \mathrm{~mm}$. long, about $1 \mathrm{~cm}$. broad or less, the cauline about $4 \mathrm{~cm}$. long, 6-12 mm. wide; heads pedicelled in an open cyme; involucres dull in color, about $6 \mathrm{~mm}$. high, the bracts unequal. Male plant unknown.

Type locality.- "Little Belt Mountains, Montana." Collected by Flodman, no. 867; type in United States National Herbarium.

The type is the only specimen of this species known to me. It is a meadow plant, whose affinities are with $A$. parvifolia.

21. Antennaria bracteosa Rydb. Mem. N. Y. Bot. Garden 1: 413.1900.

About $3 \mathrm{dm}$. high; leaves broadly spatulate, thin in texture, canescent or tomentose, $15-20 \mathrm{~mm}$. long, the cauline about $3 \mathrm{~cm}$. long; involucral bracts (pistillate) narrow, the tips white, acutish to acuminate. Male plant unknown.

Type locality.- "Jack Creek," Montana. Collected by Rydberg and Bessey, no. 5144; type in the herbarium of the New York Botanical Garden.

This is a doubtful species, as little known as $A$. foliacea. It appears to be intermediate between that and $A$. parvifolia. Its leaves resemble those of the former, while its heads are more like those of the latter. It is glandular above, with the ciliate hairs which so often appear in A. parvifolia. The plants in the two cotypes which I have examined are rather immature.

22. Antennaria parvifolia Nutt. Trans. Am. Phil. Soc. II. 7: 406. 1841.

A. microphylla Rydb. Bull. Torr. Club 24: 303. 1897, ${ }^{1}$ not Gandoger, 1887.

Slender, 1-3 dm. high; stolons short, procumbent; leaves rhomboidally spatulate and acute or rarely with the terminal dilated portion obovate and obtuse, $5-15 \mathrm{~mm}$. long, silvery-tomentose on both surfaces or only canescent above; heads in a rounded cluster or in an open corymb; involucres $5-6 \mathrm{~mm}$. high; tips of the pistillate bracts usually narrow, obtuse, or acute, dull white or somewhat yellowish; those of the staminate bracts rotund to oblong, obtuse or truncate, dull white or yellowish white.

Type locality.- "On the Black Hills and plains of the upper part of the Platte." Collected by Nuttall; type in the herbarium of the Philadelphia Academy.

Colorado, Utah, eastern Idaho, Wyoming, Black Hills of South Dakota, Montana, northward in British America to Alberta.

This is distinctively a meadow species, and therefore much later in flowering than the dry ground species of the same locality. It flowers fully a month later than $A$. aprica of the dry, open plains and slopes

${ }^{1}$ Type locality._-"Manhattan," Montana. Collected by Rydberg, no 2831; type in the Columbia Herbarium. 
and from two to three weeks later than $A$. reflexa and $A$. arida. Nearly all forms of this species are more or less glandular and green about the inflorescence and often ciliate as well. The nonglandular forms are less common and quite different in appearance, their involucres much like those of $A$. foliacea. A narrow-leaved form has been collected by Rydberg and V reeland, no. 5450, in southern Colorado.

Dr. Rydberg claims that A. parvifolia Nuttall is A. rosea (Eaton) Greene, but Nuttall's description does not apply to that plant. The leaves of $A$. rosea are not " whitely tomentose," but "canescently tomentose" and dull as to color. "Radical leaves, somewhat rhomboidal'v spatulate," exactly describes the plant which Dr. Rydberg named A. micropleylla. The stolons of A. rosea are hardly " procumbent,' but ascending or assurgent. It is also very improbable that Nuttall had staminate plants of $A$. rosea, since those are extremely rare. I doubt very much whether Nuttall would have described $A$. rosea (Eaton) Greene as having "whitely tomentose" and "somewhat rhomboidally spatulate leaves" and "procumbent sarments." If the Nuttallian specimen seen by Dr. Rydberg is A. rosea (Eaton) Greene, then we are led to believe that it is not what Nuttall had before him when drawing up his description. The characterization which Nuttall gives is of the male plant, and, apparently, he had dwarf specimens.

23. Antennaria nitida Greene, Pittonia 3: 283. 1898.

Stems 6-7 cm. high; leaves spatulate, obtusish, 7-10 mm. long, 2.5 $\mathrm{mm}$. wide, covered with a white, glistening indument; lower portion of involucral bracts and the foliar bracts of the inflorescence beset with short glandular hairs; involucres $6 \mathrm{~mm}$. high, the tips of the bracts (staminate) yellowish white, oblong to oval, obtuse, entire or bluntly few-toothed at summit. Female plant unknown.

Type locality. - "Charlton Island, James Bay." Collected by J. M. Macoun; type in the herbarium of the Geological Survey of Canada (sheet no. 11272).

A northern relative of $A$. parvifolia, characterized by its obtusish leaves and viscid indument.

\section{Antennaria arida E. Nelson, Bot. Gaz. 27: 210. 1899.}

Seven to $15 \mathrm{~cm}$. high; leaves small (8-12 $\mathrm{mm}$. long) and inclined to be conduplicate, spatulate, acute, hoary-tomentose; involucres about $6 \mathrm{~mm}$. high, the bracts (pistillate) nearly all equal, obtuse, or somewhat imbricaied and acutish, the tips dull white, very rarely pinkish. Male plant unknown.

Typelocality.- "Tipton" in "the arid region of southwestern Wyoming." Collected by Aven Nelson, no. 4798; type in the Rocky Mountain Herbarium, University of Wyoming, Laramie.

Wyoming, Utah, and Colorado.

Distinctly an arid species, being the low, hoary, whitish-bracted plant so common on plains and gentle slopes in southern Wyoming. It flowers nearly as early as $A$. aprica and at least three weeks earlier than $A$. parvifolia of the meadows. It bears some resemblance to $A$. reflexa, but is readily distinguished by its somewhat larger heads with white-tipped bracts, and by its leaves, which are acute, standing more or less erect, and inclined to be conduplicate. The leaves of $A$. reflexa, 
on the other hand, are usually spreading and always plane. From the very similar $A$. confinis of the far west it differs in being closely matted and appressed to the ground and not at all viscidulous.

Antennaria arida viscidula subsp. nov.

Size, habit, and leaves of the species, but glandular about the inflorescence, stem, and usually on the leaves below; middle portions of outer bracts (pistillate) greenish yellow or brown, the tips dirty white or pale brown.

Type locality.-Laramie Peak, Wyoming. Collected by Aven Nelson, no. 7570; type in the Rocky Mountain Herbarium, University of Wyoming, Laramie.

Wyoming, and Colorado (Rydberg and Vreeland, no. 5455, 1900). Antennaria arida humilis (Rydb.) comb. nov.

A. foliacea humilis Rydb. Mem. N. Y. Bot. Garden 1: 414. 1900.

General aspect of the species but taller, 15-20 $\mathrm{cm}$. high, rarely more; the leaves somewhat larger; the involucral bracts more unequal.

Type locality. - "Bridger Mountains," Montana. Collected by Rydberg and Bessey, no. 5149; type in the herbarium of the New York Botanical Garden.

Montana and Wyoming.

This has nothing to do with $A$. foliacea, which is a very broad-leaved species growing in meadows. It is a well-marked form of $A$. arida and may be maintained as a variety of the latter. I was at first inclined to recognize it as a species, but since it grades imperceptibly into $A$. arida I have preferred to treat it as a variety. As to habit, it is more subligneous and with longer stolons than the species, and occurs in the hills on gravelly ridges and rocky slopes rather than on the plains. In some respects it approaches $A$. oxyphylla, which has very different involucres. This variety is rather common in the hills bordering on the Laramie Plains, where I observed and collected it repeatedly in the spring of 1900 (nos. 236, 240, 247, 251, 255). Nos. 247 and 255 are of the male plant. The staminate heads are similar to those of $A$. reflexa, but larger, the tips of the pappus bristles very much dilated, and the bract tips very broad and obtuse, sordid white or very pale brown.

25. Antennaria scariosa E. Nelson, Bot. Gaz. 27: 210. 1899. ${ }^{1}$

Three to $10 \mathrm{~cm}$. high; leaves spatulate, obtuse or acutish, hoarytomentose, about $14 \mathrm{~mm}$. long; cauline leaves ample; bracts (pistillate) with broader tips that in $A$. arida.

Type locality._- "Leroy, Uinta County," southwestern Wyoming. Collected by Aven Nelson, no. 4587; type in the Rocky Mountain Herbarium, University of Wyoming, Laramie.

hh. Heads sessile and solitary or 2 or 3 together on much abbreviated rosulate-leafy stems.

26. Antennaria rosulata Rydb. Bull. Torr. Club 24: 300. 1897.

Densely matted and depressed, the heads scarcely rising above the

${ }^{1}$ I propose the new name Antennaria petaloidea modesta for A. petaloidea scariosa Fernald, Rhodora 1: 73. 1899 (April), not A. scariosa E. Nelson, Bot. Gaz. 27: 210. 1899 (March). 
leaves; these spatulate, obtuse or acutish, $6-10 \mathrm{~mm}$. long; involucres about $7 \mathrm{~mm}$. high. ${ }^{1}$

Type specimens in the Columbia Herbarium, collected by Mearns, no. 40 (Mogollon Mountains, Arizona), and by Palmer, no. 109 (Arizona).

Arizona (Palmer, no. 109; Toumey, no. 599; MacDougal) to southern Colorado (Baker, no. 627; Rydberg and Vreeland, no. 5449).

Mr. Baker's specimens, determined by Dr. Greene, were distributed under an herbarium name, but I can not see in them anything specifically distinct from the Arizonian plants.

\section{ff. Heads comparatively large, the involucres averaging $8(7-9) \mathrm{mm}$. high. ${ }^{2}$}

\section{Antennaria aprica Greene, Pittonia $3: 282$. 1898.}

A. holmii Greene, Pittonia $4: 81.1899 .^{3}$

Low and usually densely matted, less than $15 \mathrm{~cm}$. high; leaves cuneateobovate to narrowly oblanceolate, permanently tomentose on both surfaces, acute to obtuse; heads large for the plant, the pistillate involucres $6-8 \mathrm{~mm}$. high; bracts numerous and imbricated, the tips in the female plant acute or obtuse, dull white or pink, often with a brown spot at the base of the scarious portion, in the male plant broad and obtuse, white.

Dry ground along foothills and on open plains; from New Mexico northward to Assiniboia and Manitoba; also in Utah, western Nebraska, and western South Dakota.

Of this common Rocky Mountain species I have examined some 50 sheets. Though quite variable and running into numerous forms, it is well marked and readily distinguished from related species. The typical form has "cuneate-oblanceolate acutish" leaves and dull white bract tips, but forms with much broader and obtuse leaves are common, and pink-tipped bracts or brown-spotted ones may be found in most of the forms. The pistillate bracts in the majority of sheets examined are obtuse. Forms with narrower and acute or acutish bracts, however, are not uncommon, and these apparently are of frequent occurrence in southern Colorado. The male plants are much less common than the female ones. On the Laramie Plains of southern Wyoming the one is about as common as the other. The pistillate bracts have obovate or oval, obtuse tips, and the dilated portion of the pappus is linear to oblong-linear and serrate, or nearly entire. I can not regard $A$. holmii in any other light than as one of the many forms of this species.

28. Antennaria recurva Greene, Pittonia $3: 290.1898$.

Like the preceding, but less cespitose, the stolons short and stout, rooting tardily, very leafy terminally; leaves narrowly spatulate, acutish, inclined to be conduplicate and recurved near the tip, permanently hoary-tomentose on both surfaces, and more densely so beneath;

${ }^{1}$ For full description, see Pittonia 3 : 289. 1898.

${ }^{2}$ The following ally of $A$. dioica occurs in Greenland:

A. hyperborea (Winch.) Don, in Engl. Bot. Suppl. pl. 2640. 1831. Gnaphalium hyperboreum Winch. Arr. ed. 7. 3:926. 1830. Also found in northern Europe.

${ }^{3}$ Type locality. - "In open places among the more elevated pine woods on Longs Peak, Colorado.' Collected by Holm; type in the herbarium of E. L. Greene. 
involucral bracts of the female plant obtuse, fewer than in the preceding species. Male plants unknown.

Typelocality._ "Vicinity of Flagstaff, northern Arizona." Collected by MacDougal; type in the United States National Herbarium.

Apparently a good species, but little known, and founded on very immature pistillate plants, in which the stems are only an inch high.

29. Antennaria marginata Greene, Pittonia 3:290. 1898.

Like $A$. aprica, but leaves glabrous above, or nearly so, and prominently mucronate; staminate involucral bracts with rhomboid-ovate and obtuse or acute tips.

Type in the United States National Herbarium, collected in New Mexico by Fendler; nos. 523 (male), 521a (female).

New Mexico and southern Colorado.

A New Mexican ally of A. aprica, which it appears to replace almost entirely in that territory. It is often somewhat suffrutescent, and the old leaves are occasionally conduplicate and recurved, as in the preceding species. It is more or less glandular above, with minute glandtipped hairs on the pedicels, foliar bracts, and outer involucral bracts. The typical specimens are from $3-8 \mathrm{~cm}$. high, but the species is often $15 \mathrm{~cm}$. high, or more. The involucral bracts of the male plant are subcoriaceous up to the ovate or lanceolate acutish petaloid portion. It has been collected by G. C. Nealley, no. 46, Pinos Altos, New Mexico, and by Rydberg and V reeland, in southern Colorado. Less typical specimens have been secured by Mr. Heller, no. 3612, near Santa Fe.

30. Antennaria insularis Greene, Pittonia 3:276. 1898.

Five to $10 \mathrm{~cm}$. high; leaves broadly spatulate or obovate, only abruptly acute, glabrous or glabrate above; pistillate involucres $7-8 \mathrm{~mm}$. high.

Type locality. - "Islands off the Alaskan coast." Collected by Baker (Kiska Island) and by Townsend (Adakh Island); type sheets in the United States National Herbarium.

Alaska (L. M. Turner, 1880) and adjacent islands.

This bears a superficial resemblance to the southern $A$. marginata, but is a broader-leaved species, with heads more like those of $A$. aprica.

31. Antennaria oxyphylla Greene, Pittonia 4: 284. 1901.

Fifteen to $25 \mathrm{~cm}$. high; leaves spatulate-obovate, permanently tomentose on both surfaces, $2 \mathrm{~cm}$. long or less; heads 6-15; involucres 7-8 $\mathrm{mm}$. high; bracts in about 4 series, imbricated, "all acute and of a rather dull white," rarely pinkish. Male plant unknown.

Type locality._. "Spanish Basin, Gallatin Co., Montana." Collected by Rydberg and Bessey, no. 5148; type in the herbarium of E. L. Greene.

Southern Wyoming to the Black Hills of South Dakota, Montana, and southeastern British Columbia.

This is a dry ground species, in general appearance resembling $A$. rosea and $A$. parvifolia, but its comparatively large heads, with numerous involucral bracts, show it to be an ally of $A$. obovata and $A$. aprica. The involucral bracts are not as narrow as those of the former and more acute than those of the latter. Dr. Greene founded the species 
on somewhat immature specimens, the heads not being fully developed. Maturer specimens have been collected by Leslie Goodding (no. 7288 of the Rocky Mountain Herbarium) in the Laramie Hills, southern Wyoming, June 12, 1900. Dr. Rydberg's no. 795 from the Black Hills exemplify the species in its mature condition, and John Macoun has secured it at Deer Park, Lower Arrow Lake, British Columbia, 1890.

aa. Leaves comparatively large. Segregates of the A. Plantaginifolia of the Synoptical Flora; western allies of A. NEgLecta. Only the fertile plants known.

32. Antennaria obovata E. Nelson, Bot. Gaz. 2\%: 213. 1899.

Two to $3 \mathrm{dm}$. high; leaves permanently tomentose on both surfaces, 3-5 cm. long, the blade cuneate-obovate, obtuse, and about $13 \mathrm{~mm}$. broad.

Type locality._- "Near Soldier Cañon," Colorado. Collected by Cowan; type in the herbarium of Colorado Agricultural College.

Foothills along the eastern base of the mountains in Colorado and in the Black Hills of South-Dakota (Forwood no. 228a, Rydberg no. 793).

33. Antennaria pedicellata Greene, Pittonia 3:175. 1897.

Like $A$. howellii, but leaves smaller, oblanceolate, acute, with no distinction of blade or petiole and permanently tomentose on both surfaces.

Type locality._- "Blue Mountains of Oregon." Collected by Howell, no. 1522; type in the herbarium of E. L. Greene.

A little-known species, closely related to the following. The type specimen is quite noticeably giandular on the leaves, stem, pedicels, and outer bracts of the involucres. G. R. Vasey's•no. 485, from Washington, seems to belong here.

\section{Antennaria howellii Greene, Pittonia 3:174.1897.}

Two to $3 \mathrm{dm}$. high; stolons slender and prostrate; leaves usually distinctly petioled with cuneate-obovate, acute or acutish blades, glabrous above or nearly so, $3-5 \mathrm{~cm}$. long.

Type locality._-"Mt. St. Helen, Oregon." Collected by Howell; type in the herbarium of E. L. Greene.

Oregon to British Columbia and eastward to western Montana.

Typical specimens have leaves which are glabrous above but plants with the leaves arachnoid on the upper surfaces are not uncommon. The heads are often on pedicels as long as those of $A$. pedicellata.

35. Antennaria petasites Greene, Pittonia 3: 277. 1898.

Eighteen to $27 \mathrm{~cm}$. high; cauline leaves, ample, green, and glabrous above, $2-3 \mathrm{~cm}$. long, $5 \mathrm{~mm}$. broad; heads panicled, the panicle conspicuously leafy-bracted.

Type locality._- "Sterile knolls and banks, Drew's Harbour, British Columbia." Collected by Dawson; type in the herbarium of the Geological Survey of Canada (sheet no. 11292).

The type consists of two plants without radical leaves or stolons. The species appear to be related to $A$. hovellii, whose cauline leaves are small and inconspicuous. 


\section{$2 \mathrm{BHL}$ Biodiversity Heritage Library}

Nelson, Elias. 1901. "A revision of certain species of plants of the genus Antennaria." Proceedings of the United States National Museum 23(1230), 697-713. https://doi.org/10.5479/si.00963801.1230.697.

View This Item Online: https://www.biodiversitylibrary.org/item/32360

DOI: https://doi.org/10.5479/si.00963801.1230.697

Permalink: https://www.biodiversitylibrary.org/partpdf/26650

\section{Holding Institution}

Smithsonian Libraries

\section{Sponsored by}

Smithsonian

\section{Copyright \& Reuse}

Copyright Status: NOT_IN_COPYRIGHT

This document was created from content at the Biodiversity Heritage Library, the world's largest open access digital library for biodiversity literature and archives. Visit BHL at https://www.biodiversitylibrary.org. 